\section{Good Posture Is Essential To Good Microscopy}

Stephen A. Shaffer, MicroDataware

Let's face it. Looking through a microscope is not what our bodies were built for, and looking through a microscope for an extended period of time requires an unnatural rigidity of the body. You're not moving around, even a bit, as you normally would. The result can be cramped muscles, especially in the neck and shoulders, and a whole body fatigue that can make 10:00 AM feel like 5:00 PM. The solution is correct posture and a proper arrangement of microscope, chair, and body.

1) If you're going to be doing microscopy for any length of time, insist on a good, adjustable, ergonomically-designed chair!

2) Adjust the height of the chair so your feet can rest comfortably on the floor with an even pressure along the back of the thighs. It may be advantageous to tilt the seat of the chair slightly down in front to eliminate any pinch at the back of the knees.

3) Note: Adjust the chair height without regard to the microscope height!

4) Adjust the position of the microscope so that you can comfortably gaze into the eyepieces without leaning significantly forward. This requires two adjustments:

a. Set the lateral position of the microscope so that it is close to the front edge of the bench with the eyepieces no further away from you than the front edge of the bench.

b. Set the vertical position of the microscope so that it is a bit high for comfortable viewing. This will nomally require elevating the microscope on some type of stand on top of the bench. The idea is to farce yourself to straighten your back as you draw up to the microscope, so that with extended viewing your back is straight and your head in an upright position. Look down into the eyepieces by letting your eyes view at a downward angle. Do not bend the neck to look into the micro scope eyepieces. "

5) Obtain some type of arm rest for the arm used to focus the microscope, so that you don't need to be constantly raising the arm off the bench surface, and so that you are not tempted to say "Oh, the focus is good enough" to yourself while you work. Constant, continuous focusing of the microscope is essential to minimize eye strain. (As an aside. proper setting of inter-pupillary distance and making sure the eyepieces are parfocal are also essential to minimizing eye strain.)

6) After you've established the optimal height for your microscope by propping it up on phone books, this moming's paper, or whatever - you may wish to have a permanent stand fabricated to the right height. Consider incorporating one or two arm rests into the design. Go on, it won't cost you much and it will make a world of difference in your comfort as you work. No point growing old and crooked before your lime.

7) Take a break from time to time. Get up, walk around, stretch arms, back, neck, and legs to remove any kinks that may be forming belore they become a bother.

- Ed. note: Several microscope manufacturers now have available oculars that are, or can be positioned, at $90^{\circ}$ to the body of the microscope. That is, horizontal, so the user can look straight-ahead to see into the oculars, and does not have to look down into them. This is an ergonomically better design.

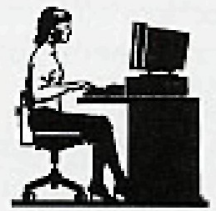

\section{EMITECH}

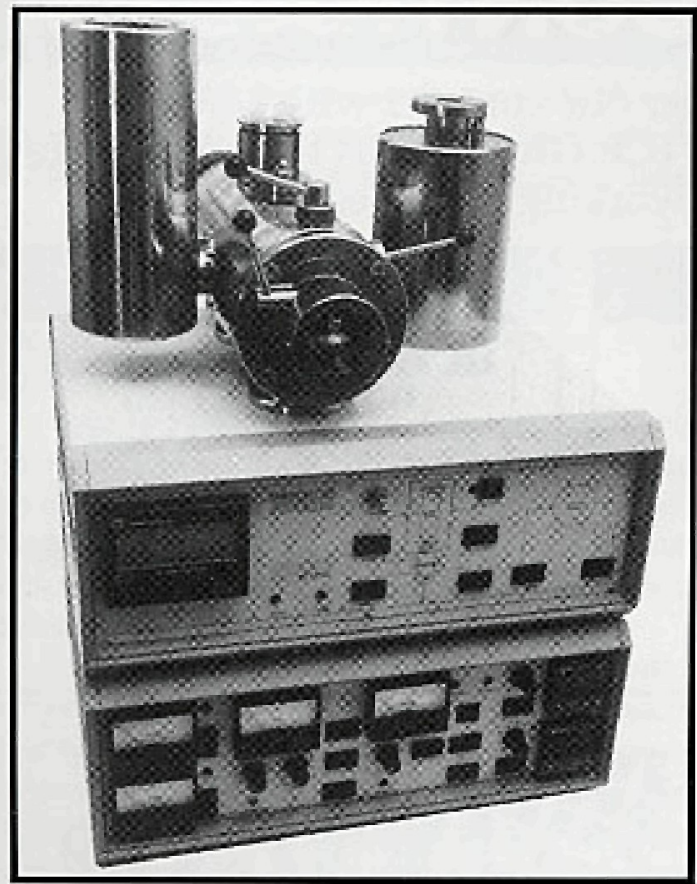

The K1250 System with Unique Cylinder Preparation Chamber and Turbomolecular Pumping Unit

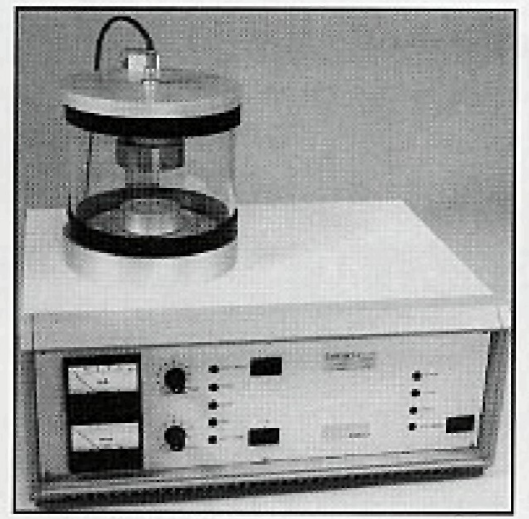

The K550 Automatic Coater

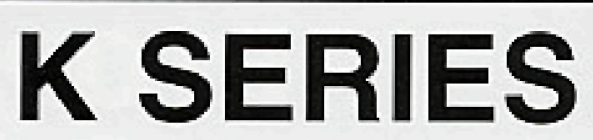

ENTECH OFFERS A FULL LINE OF SPECIMEN PREPARATION EQUIPMENT INCLUDING SFUTTER COATERS, TURBO SPUTIER COATERS, EVAPORATORS, FREEZE DRIERS, CPDS AND CRYOGENIC SYSTEMS WITH A 2 YEAR WARRANTY ON AL SYSTEMS.

EMITECH USA, INC.

Tel: 800/444-3137 - Fax: 281/893-8443

www.emitechusa.com • Email:emitech@ix.netcom.com 
- Quartz Halogen Light Sources

- Ringlights - Standard and ESD Safe - Dual and Single Self-Supporting Light Guides - Microscope Accessories

- Fast Delivery - Aggressive Pricing

- Innovative Products and Accessories

- Custom and OEM Copabilities

- Quality Products for over 35 years - Lifetime Warranty

\section{See our website for NEW product information!}

Attention Microscope Dealers:

Dolan-Jenneris interested in growing our distribution channel through building relationships with microscope dealers.

Pleose call Gus Vassiliades at ext. 3076 for more information.

\section{Fiber Optic Illumination}

for Microscopy
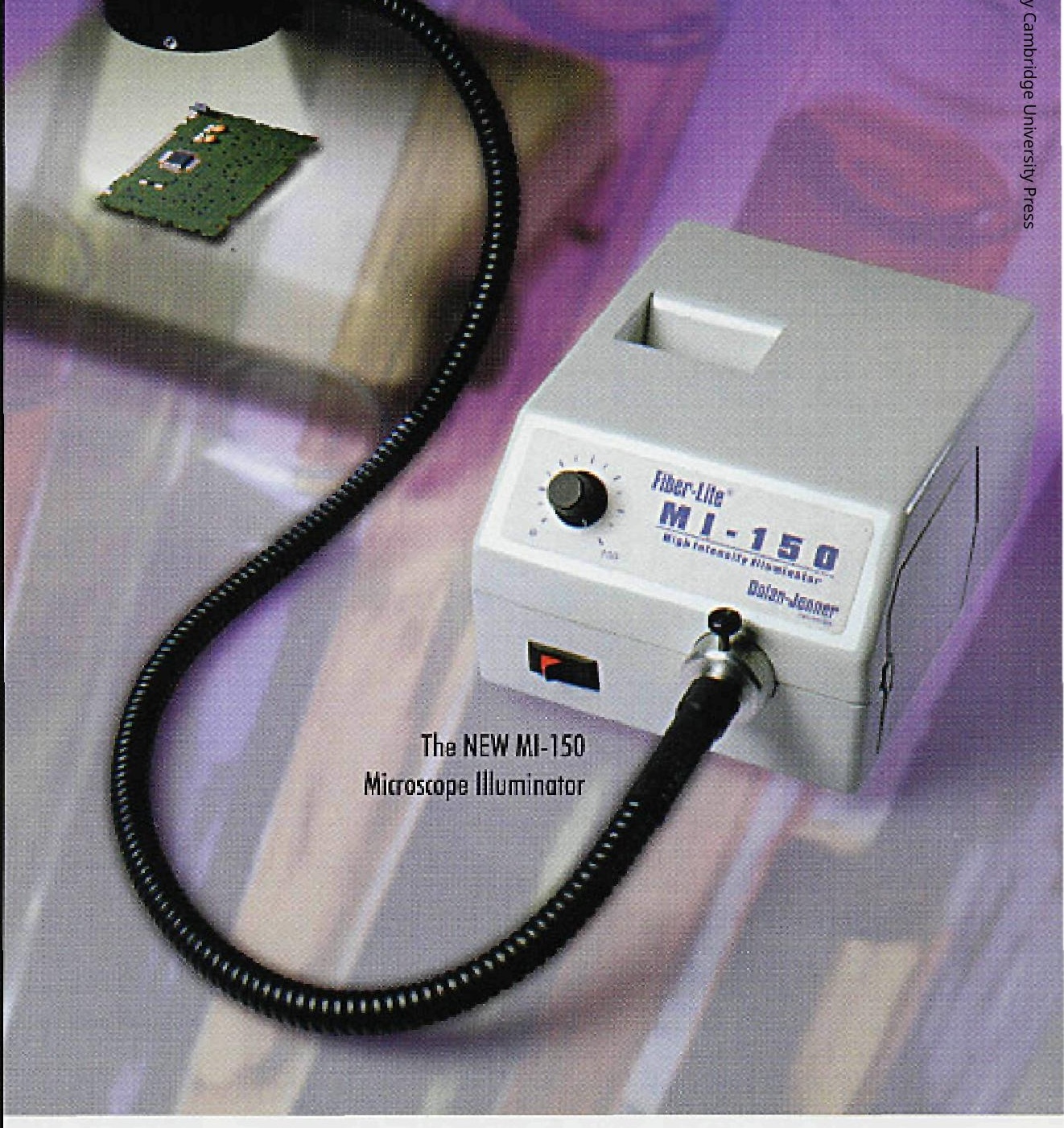

"The Right Product for the Light Application"

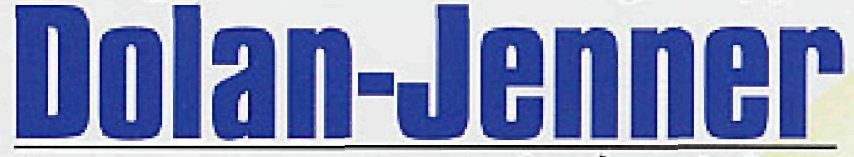

678 Andover Street Lawrence, MA 01843

Fax 978.682 .2500

sales@dolan-jenner.com industries

1-800-83FIBER $(8334237$ ) www.dolan-jenner.com 


\section{EDS Upgrades}

Upgrade your existing EDX system with the world leader in affordable EDX upgrades.

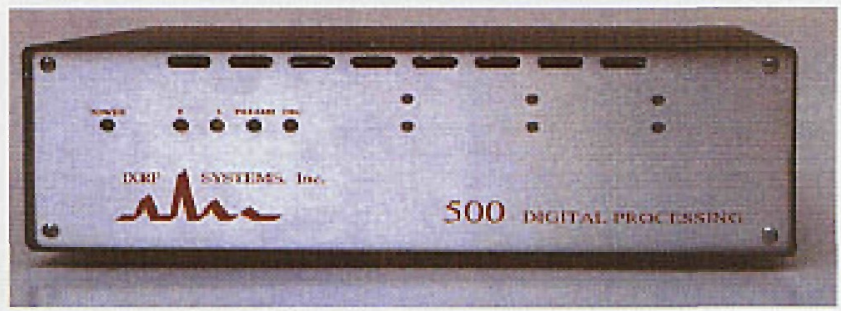

Our new digital pulse processor provides increased throughput and will interface to most EDS detectors.

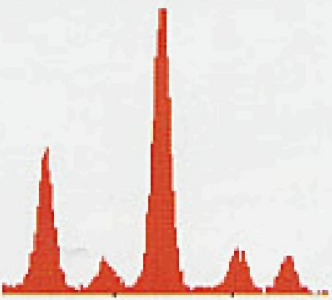

Precise Standardless quantitation for even complex matricies

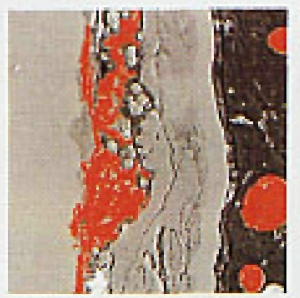

"Active" digital imaging, linescans, and $x$-ray mapping.
Combining digital imaging with our EDS system produces a very simple yet powerful Microanalysis system.

IXRF has established it-self as a "leader" in the Microanalysis industry as most of the major EDS companies convert from analog to digital systems.
Hundreds of systems installed
- Easy to use Windows 95 or NT
- Each system comes complete with Pentium PC
- Installation and training at your site
New detectors available
Morphology and Feature analysis
Automatic Point Analysis
- Quantitative Mapping and Linescans

IXRF Systems, Inc. 15715 Brookford Dr.

Houston, TX 77059

Tel:281/286-6485 Fax:281/286/2660

Website: ixrfsystems.com

\section{REMEMBER WHEN:}

A COMPUTER WAS SOMETHING ON TV

FROM A SCIENCE FICTION SHOW

A WINDOW WAS SOMETHING YOU HATED TO CLEAN.

AND RAM WAS THE COUSIN OF A GOAT

MEG WAS THE NAME OF MY GIRLFRIEND AND GIG WAS SOMETHING YOU DID ON STAGE FOR MONEY NOW THEY ALL MEAN DIFFERENT THINGS AND THAT REALLY MEGA BYTES

AN APFLICATION WAS FOR EMPLOYMENT

A PROGRAM WASA TV SHOW

A CURSOR USED PROFANITY

A PIANO HAD A KEYBOARD

MEMORY WAS SOMETHING THAT YOU LOST WITH AGE

A CD WAS A BANK ACCOUNT

AND IF YOU IF YOU HAD A $3 \gamma^{2}$ FLOPPY

IT IS ON YOUR HEAD IT WOULD MOUNT

COMPRESS WAS SOMETHING YOU DID TO THE GARBAGE

NOT SOMETHING YOU DID TO A FILE

AND IF YOU UNZIFPED ANYTHING IN PUELIC

YOUD BE IN JAIL FORA WHILE

LOG ON WAS ADDING WOOD TO THE FIRE

HARD DRIVE WAS A LONG TRIP ON THE ROAD

A MOUSE PAD WAS WHERE A MOUSE LIVED

AND A BACKUP HAPPENED TO YOUR COMMODE

CUT YOU DID WITH A. POCKET KNIFE

PASTE YOU DID WITH GLUE

A WEB WAS A SPIDER'S HOME

AND A VIRUS WAS THE FLU

I GUESS I'LL STICK TO MY PAD AND PAPER

AND THE MEMORY IN MY HEAD

I HEAR NOBODY'S BEEN KILLED IN A COMPUTER CRASH

BUT WHEN IT HAPPENS, THEY WILL WISH THEY WERE DEAD

Anothar contribution from Jina Carvalio, University of Hawail. Again, author is unknown

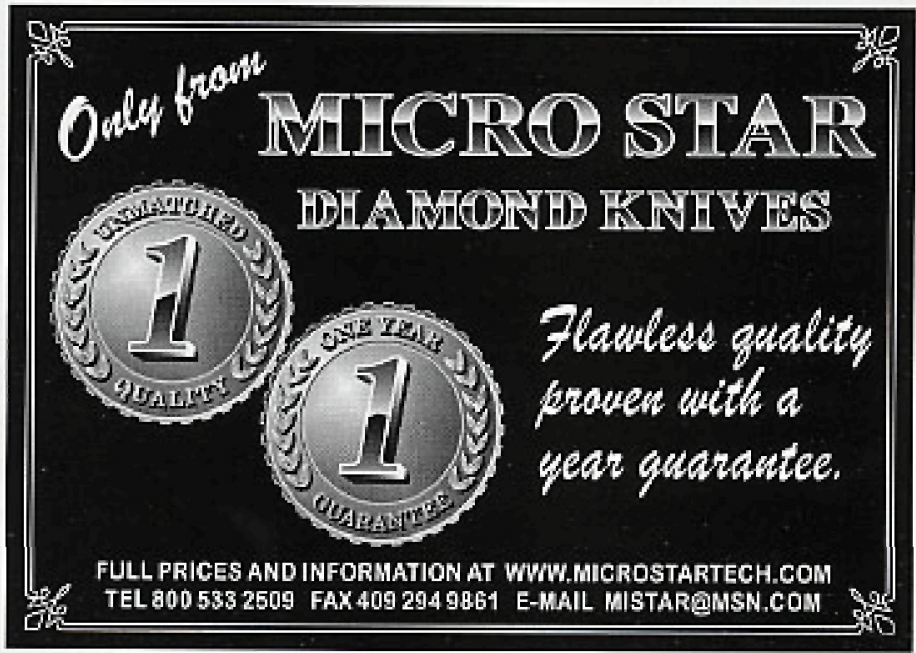

